\title{
Research on the Promotion Role of Weibo on Public Art Education in Colleges and Universities*
}

\author{
Yingfu Zhang \\ Academy of Fine Arts \\ Zhoukou Normal University \\ Zhoukou, China 466001
}

\begin{abstract}
The advent of the information age has had a profound impact on university education. As a popular new media, Weibo will play an important role in the public art education in colleges and universities. This paper analyzes the main problems, discusses the role and application strategies of Weibo in public art education, and aims at promoting the development of public art education of colleges and universities in China.
\end{abstract}

Keywords-Weibo; public art education in colleges and universities; promotion role

\section{INTRODUCTION}

Along with the rapid development of economic globalization and modern science and technology, the external environment of China's higher education has undergone tremendous changes. Moreover, it also affects public art education in colleges and universities and brings profound changes in the aspects of educational concept, educational environment, teaching management and guarantee mechanism. With the deepening of international exchanges and cooperation and the continuous deepening of China's education reform, the demand on higher education that improves students' aesthetic and humanistic qualities and promotes the healthy growth of students has been continuously enhanced. At present, the development of public art education of colleges and universities in China is still a weak link, which can not fully meet the reality needs. Therefore, it is necessary to take effective measures to deal with and solve the problems. As a new widely popular social network platform among college students, Weibo has a profound influence on college students' behavioral styles and thoughts and ideas with its powerful functions. Meanwhile, it has also injected new vitality into the public art education in colleges and universities. How to apply Weibo to teaching links has gradually become an important issue in the research of public art education in colleges and universities.

\section{Problems of Public ART EdUCATION IN COLLEGES AND UNIVERSITIES}

Public art education is the main way and content for

*Project fund: Phrased Achievements of "Study on the Development of Public Art Education in Colleges and Universities in Henan Province" (Project No.: 132400411024) of Scientific Research Project of Henan Department of Science and Technology in 2013. colleges and universities to implement aesthetic education. It plays an inestimable role in cultivating one's taste, perfecting personality, enhancing overall quality and cultivating innovative thinking. With the implementation of national education plan and the in-depth promotion of quality education it has put forward higher requirements for higher education. Colleges and universities has gradually deepened and systematized the researches on public art education, and they have tried many forms to promote the development of public art education. However, due to many reasons, there are still many problems to be solved in the public art education in China's colleges and universities.

\section{A. Lagging Ideas of Public Art Education in Colleges and Universities}

Public art education is an important part of China's higher education. "Under the prevalence of pragmatism, the utilitarian teaching content and the employment orientation has made public art education become popular among students in many universities, however, it can not attract the concerns of leadership and become 'things of little value or interest' ", 1 and the lagging educational ideas lead to the absence of public art education in colleges and universities.

\section{B. The Shortage of Public Art Education Resources in Colleges and Universities}

Due to unremarkable dominant effect and lack of required concerns of public art education, the insufficient investment in public art education, poor teachers and curriculum construction, imperfect software and hardware facilities, weak art practice, lack of guarantee mechanism, and other factors have become the main reasons that hinder the reform and development of public art education in Chinese colleges and universities.

\section{Obsolete Methods of Public Art Education in Colleges and Universitie}

The situation that "nobody concerns" public art education has also greatly affected teachers' enthusiasm and selfconfidence in public art teaching research. According to the survey, most college teachers adopt traditional education

\footnotetext{
Universities

The Development Status of Public Art Education in Colleges and

[EB/OL].http://fzghc.blcu.edu.cn/art/2014/7/14/art_6582_1076430.html.
} 
concepts and methods in the process of public art education, and their teaching methods are out of date and simple and they have limited recognition to use new media including Weibo and WeChat.

Moreover, there are problems in public art education that needs to be found and tackled in terms of teacher arrangement, course construction, communication channels and evaluation system. The duck-stuffing education method and boring teaching content make many students be bored with public art, which seriously affects the function of public art education in colleges and universities.

\section{The Role OF WeIBo IN THE PUBLIC ART EDUCATION IN COLLEGES AND UNIVERSITIES}

Weibo, MicroBlog for short, is a broadcast social networking platform that shares short and real-time information by paying attention to mechanism. It mostly shares the information published by the users in the form of rebroadcast through the platform of the Internet and carries out interaction by means of leaving a message, moreover, it is not limited to time, place, and main object of operation. The diversification also appears on the detailed information distribution. The way to publish information is also diversified, and mobile phones, IM, and Web are all major media." ${ }^{2}$ the influence and explosiveness of Weibo have caused "microrevolutionary phenomena" with an extremely wide range. The characteristics of the effectiveness of Weibo information interaction have increased people's information autonomy, improved their interactivity, and subtly affected people's production and life. Meanwhile, the influence of Weibo has also penetrated into the field of education in colleges and universities. "For colleges and universities, teachers or students, the grasp of the development of new media technology and the mastery and integration ability of art education resources are powerful bargaining chips for the reform and innovation of public art education in colleges and universities." 3 the role of Weibo in public art education of colleges and universities is mainly reflected in the following aspects:

\section{A. Weibo Has Changed the Way of Public Art Education in Colleges and Universities}

The traditional teaching of public art education is that teachers give lectures to students by face to face. Under such circumstances, there are limited methods and ways for students to receive art education, and teachers' teaching effect is also affected. The openness of Weibo education resources has make art education "ubiquitous", making up for the deficiency of traditional classroom teaching. The freedom of interactive comments on Weibo has satisfied the need of students' freedom of speech and self-expression, and enabled students to participate in art activities more actively and proactively. Thanks to its powerful functions, Weibo makes it easier for

\footnotetext{
2 Zhang Siqi: Research on Weibo Culture [D]. Jilin University, 2012 (12): 4-5.

3 Huang Tingting, Zhang Kaici: Feasibility Study of Microblog
} Education of University Public Art Edcation [J]. Hundred Schools in Arts. 2014 (05): 219. teachers to share the teaching content by means of words, pictures, videos or links. Teachers also can learn teaching effect and student' learning situation based on students' attention on blog and comments on its content, which facilitates the harmonious unity of teaching and learning.

\section{B. Weibo Has Expanded the Scope of Public Art Education in Colleges and Universities}

As a popular expression and communication tool, Weibo is often employed by student group. Therefore, scientific and reasonable use of Weibo that students are interested in to strengthen public art education can achieve a multiplier effect. For example, teachers can upload the related information of art in a targeted and timely manner, and students will select and share content that they are interested in. By that analogy, the students who pay attention to teachers are followed and promoted by their followers. As a "broadcast" social networking platform, Weibo publishes art information in the "fissile" form of "one-to-many, many-to-more again", which breaks the limitations of identity and region, strongly promotes the interaction and communication between art activities and art works, and makes more people become the beneficiaries and disseminators of education.

\section{Weibo Has Enriched the Content of Public Art Education in Colleges and Universities}

Because of unlimited Weibo topics, bloggers can release what they have seen, heard, felt, thought and done in anywhere or for anytime. Characterized by timeliness, convenience and interaction, Weibo can present the fragmented information by using fragmented time, which enriches the content of traditional public art education characterized by long time and systematization. On Weibo platform, teachers and students can upload, share, and comment on excellent art works from different periods and countries at any time. Various opinions on arts by Weibo celebrities and professionals have become an important source of public art education after class. These "extracurricular" educational resources are more likely to arouse the attention of students, and then stimulate their discussion and analysis. The process of students' active discussion and in-depth analysis on art works is also a process that students are imperceptibly affected by art education and art edification.

\section{The ApPliCATION OF WeIBo IN Public ART EDUCATION IN COLLEGES AND UNIVERSITIES}

\section{A. Using Weibo to Construct a Harmonious Campus Art Environment in Colleges and Universities}

The development of the times and changes in the environment at home and abroad cause more complicated problems of China's education. Some famous quotations also reveal the decisive effect of environment on things, for example, "Disorderly living hemp medium, don't hand but keep, white the sand is in the Nie, with it accompany black." in To Encourage Learning and "orange will be itself in the south and will be trifoliate orange in the north" in Yanzi' s Spring and Autumn Annals. It is well known that the construction of harmonious campus culture is of great significance to 
enlightening students' minds, cultivating students' sentiments, purifying students' hearts, developing good behavior habits, and forming a correct world outlook, outlook on life, and values. Therefore, colleges and universities should adhere to the people oriented educational concept, highlight the applicability and inclusiveness of public art education, encourage teachers, students and art associations to combine art exhibitions, events or art festivals, and other art activities, disseminate healthy, safe and civilized art information in time through Weibo platform, and create a harmonious, open, and rich campus culture and art atmosphere, so that students can deepen their understanding and learning of public art education in the process of scientifically using Weibo and actively focusing on Weibo, thus enhancing the function of Weibo in the service of public art education and educating people.

\section{B. Promoting Excellent Campus Cultural Brands in Colleges and Universities with the Help of Weibo}

The integration of Weibo and education is an important trend and direction to explore modern education reform. Compared with traditional education, as a new media education platform, Weibo can achieve cultural transmission of various art information, such as words, pictures, videos, images and so on, and the quick, vivid and visual information dissemination way conforms to the current learning and studying habits of college students. By using the personalized features of Weibo, teachers can make elaborate disposal for the content of public art education and timely transmit the art information to students and make students break the limitation of classroom learning, so as to achieve the effective teaching in the life and art practice process. For example, the series of lectures of "listening music and appreciating art" held by Zhoukou Normal University are the brand of public art education of this university. With the help of provincial art education center platform, the school can timely upload the information and content of lectures to Weibo and transmit the related art education courses to the students through Weibo, so as to provide a platform for students to conveniently learn about art knowledge and do free thinking and discussion after class. Only recognized and supported by students, it can attract more students' active attention and encourage them actively participate in, and make them become subjects of learning and dissemination of public arts education resources, and then strengthen the function of Weibo services in educating people in public arts.

\section{Strengthening the Public Art Practice Education in Colleges and Universities through Weibo}

Art theory education is much more boring than art practice education. Therefore, artistic phenomena and artistic activities in life are taken as teaching cases in the process of public art education, which avoids the embarrassment of teachers' description without foundation, facilitates dispelling the distance between students and life and education, stimulates students' desire for knowledge, enthusiasm and creativity, and promotes harmonious development of students' cognition, emotion, attitude and skills. First, combine art activities to strengthen public art practice education. Universities can publish information on art activities including painting, calligraphy, photography, singing, dancing and performance through the Weibo platform, so that more students can learn the content of the activities and can be attracted to participate in the activities. Universities provide students with the opportunities of thinking, hands-on practice and self-display through serialized, specialized and regular art activities, so as to improve students' aesthetic and practical ability. Second, combine exhibitions and competitions to strengthen public art practice education. For example, Academy of Fine Arts of Zhoukou Normal University is based on the view of "extensive fine arts", and its graduation exhibitions of "creating for the local" have been rich in content and diverse in form for many years. The Academy can organize students to continuously push the graduation works about Chinese micrographs, oil paintings and animations on Weibo platform. As students are familiar with the subject matter of graduation design, they can also understand the artistic value and humanistic spirit contained in the exhibition. Universities use Weibo platform to disseminate artistic activities, exhibitions and events, cultivate students' habits and awareness of actively focusing on Weibo, participating in the review, and transmitting art information, train students' ability to apply new media, organize language, and practice, and continue to strengthen Weibo's function in educating people in public art education.

\section{CONCLUSION}

To sum up, the effective combination of Weibo and public art education has brought new opportunities for public art education in colleges and universities. On the one hand, the equality of the Weibo platform has facilitated interactions and exchanges between teachers, and between students, effectively made up for the deficiencies and shortcomings of traditional teaching, improved the limitations brought about by the complexity of the relationship between teachers and students, so that the teaching process becomes more interactive and efficient; on the other hand, the openness of Weibo platform has provided students with a vast number of public art education resources, satisfied the diverse needs of different students, and enhanced students' enthusiasm and initiative in learning and practice. Meanwhile, as a major auxiliary means of classroom teaching, the convenience of the Weibo platform enables students to understand local and exotic cultures without limitations of space and time, and greatly enriches the content of public art education, so that the college education becomes more fresh, vivid and interesting. At present, Weibo has become a new classroom for college education. Only scientific and rational use of Weibo can promote the innovation and development of public art education in colleges and universities, and highlight the characteristics that colleges and universities cultivate students by using culture.

\section{REFERENCES}

[1] Huang Tingting, Zhang Kaici. Feasibility Study of Microblog Education of University Public Art Edcation [J]. Hundred Schools In Arts. 2014 (05) 黄婷婷, 张凯茨.高校公共艺术教育微博教育的可行性研究 [J]. 艺术百家.2014（05）

[2] Zhang Xuan. The Status Quo and Reform of Public Art Education in Colleges and Universities [J]. Academic Exchange. 2012 (06) 张炫.普 通高等院校公共艺术教育的发展现状与改革思路 [J]. 学术交 流.2012(06) 
[3] Li Yuchun. Study on the Combination of Public Art Education and Professional Education in Application-oriented Colleges and Universities [J]. Literature and Art Forum. 2014 (10) 李昱春.应用型本 科高校公共艺术教育与专业教育相结合初探 [J]. 文艺争鸣.2014 (10)

[4] Xu Ying. Discussion on Public Art Education under New Media Environment [J]. Journal of Chifeng University (Chinese Philosophy and Natural Science Edition). 2013 (04). 徐颖.刍议新媒体环境下的公 共艺术教育 $[J]$. 赤峰学院学报(汉文哲学社会科学版).2013 (04)。 